\title{
Synthesis, in silico Study, Theoretical Stereochemistry Elucidation and Antifungal Activity of New Imides Derived from Safrole
}

\author{
Raquel F. Vilela, ${ }^{a}$ Normando A. S. Costa, ${ }^{b}$ Helivaldo D. S. Souza, ${ }^{(1)}$ Luiz E. G. Cruz, ${ }^{a}$ \\ Kelyonara M. S. de Assis, ${ }^{a}$ Edeltrudes O. Lima, ${ }^{b}$ Laísa V. Cordeiro, ${ }^{b}$ Bruno F. Lira, ${ }^{a}$ \\ Petronio F. de Athayde-Filho, ${ }^{a}$ Gerd B. Rocha ${ }^{a}$ and José M. Barbosa-Filho ${ }^{\circledR *, b}$ \\ ${ }^{a}$ Departamento de Química, Universidade Federal da Paraíba, 58051-900 João Pessoa-PB, Brazil \\ ${ }^{b}$ Departamento de Ciências Farmacêuticas, Universidade Federal da Paraíba, \\ 58051-900 João Pessoa-PB, Brazil
}

\begin{abstract}
Ten imides derived from safrole, $\mathbf{4} \mathbf{a}-\mathbf{4} \mathbf{j}$, were synthesized and their structures were fully characterized by infrared (IR) spectroscopy, ${ }^{1} \mathrm{H}$ and ${ }^{13} \mathrm{C}$ nuclear magnetic resonance (NMR) spectroscopy and high resolution mass spectrometry (HRMS) analysis. Among the ten imides studied, eight are new. The compounds were evaluated in an in silico study and showed strong to moderate antifungal activity against various strains of Candida and Cryptococcus. In particular, compounds $\mathbf{4 b}, \mathbf{4 c}$ and $\mathbf{4 h}$ exhibited strong antifungal activity, with minimum inhibitory concentration (MICs) between $0.17-0.73 \mu \mathrm{mol} \mathrm{mL}^{-1}$. The compound $\mathbf{4 j}$ exhibited antifungal activity with MIC $1.28 \mu \mathrm{mol} \mathrm{mL} \mathrm{m}^{-1}$ for all strains tested. In silico studies of the parameters of Lipinski's rule of five indicated that these compounds are potential new drug candidates. The predict oral bioavailability can be evaluated through these parameters. In addition, a computational study helped assigning the stereochemistry of compound $\mathbf{4 j}$, where the synthesized mixture is composed by two stereoisomers, $\mathbf{4 j}(1)(S R R)$ and $\mathbf{4 j}(2)(R S S)$.
\end{abstract}

Keywords: imides, safrole, Candida, Cryptococcus

\section{Introduction}

There is a need for more research on the development of new antifungal drugs as indicated by worrisome increase in the frequency of opportunistic fungal infections, particularly those caused by Candida spp. and Cryptococcus spp. ${ }^{1}$ Opportunistic infections are a serious public health problem, affecting mainly the hospital setting. Meanwhile, the most susceptible patients are those who are immunocompromised with acquired immunodeficiency syndrome (AIDS) or tuberculosis or transplanted. In these patients, the function of polymorphonuclear leukocytes is depressed, so leukocyte adhesion along with chemotaxis and phagocytosis can be affected leading to possible opportunistic fungal infections. ${ }^{2}$

Cyclic imides represent one of the important classes of compounds characterized as substances that contain the CO-NR-CO- group, where $\mathrm{R}$ is a hydrogen, alkyl group or aryl group. Among them are the maleimides, succinimides,

*e-mail: jbarbosa@1tf.ufpb.br phthalimides and glutarimides, which make up an important group of compounds that are biologically active and of substantial importance in medicinal chemistry. Heterocyclic imide analogues of the natural alkaloid phyllanthimide, isolated from Phyllanthus sellowianus ${ }^{3}$ were described by various research groups. ${ }^{4}$ However, the structures of the imides depend on the conditions of the environment. Studies carried out by Sortino et al..$^{5}$ with $N$-phenyl and $\mathrm{N}$-phenylalkyl against fungi, where the stability of the structures to the aqueous medium was evaluated, show that the substituted maleimides do not suffer from ring opening, unlike the unsubstituted maleimides that suffer opening the imidic ring in aqueous medium. ${ }^{6}$ Among these and other imides, several synthesized compounds exert important biological activities, including antibacterial, ${ }^{7}$ antifungals, ${ }^{7}$ analgesics, ${ }^{8}$ anticancer ${ }^{9}$ and others.

Safrole is a phenolic ether of the arylpropanoid class. It is a slightly yellow liquid with a characteristic odor of natural occurrence and shows higher concentrations in plants of the families Aristolochiceae, Lauraceae and Piperaceae. ${ }^{10}$ Many studies have been carried out with 
safrole, and it should be emphasized that it has been of great importance in the synthesis of new compounds with small chemical transformations, thus obtaining derivatives with anticancer, ${ }^{11}$ antibacterial, ${ }^{12}$ antifungal, ${ }^{13}$ anti-inflammatory, ${ }^{14}$ and analgesic ${ }^{15}$ activities.

Therefore, taking into account the potential of cyclic imide and safrole derivatives in the design and preparation of drug candidates, we synthesized novel compounds derived from cyclic imides using safrole. We tested these compounds for antifungal activity against strains of the genera Candida and Cryptococcus and theoretically assessed the potential of these compounds to become new drug candidates on the basis of an in silico study according to the Lipinski's rule of five using freely available programs.

\section{Results and Discussion}

\section{Chemistry}

Due to mainly important antimicrobial activities present in these compounds, nine cyclic imides were prepared, of which eight had not been previously published. The synthetic route for the preparation of the compounds was according to the procedure described in the literature, ${ }^{16,17}$ and the compounds were obtained in the three synthetic steps described in Scheme 1. The first step consisted in the isomerization of safrole (1) to obtain isosafrole (2) in a basic solution of $3.0 \mathrm{M} \mathrm{KOH}$ in $n$-butanol which was refluxed for $6 \mathrm{~h}$. In the second step, the anhydride (3) was formed by the reaction of the isosafrole (2) with maleic anhydride during reflux for $4 \mathrm{~h}$, using $o$-xylene as solvent. The anhydride was characterized by infrared (IR), ${ }^{1} \mathrm{H}$ and
${ }^{13} \mathrm{C}$ nuclear magnetic resonance (NMR) spectroscopy. In IR, the absorption bands of the $\mathrm{C}=\mathrm{O}$ functional group of the anhydride appeared around 1789 and $1724 \mathrm{~cm}^{-1}$. $\mathrm{C}=\mathrm{C}$ stretching of aromatic rings occurred at 1497 and $1479 \mathrm{~cm}^{-1}$. The C-O stretching band was around $1031 \mathrm{~cm}^{-1}$. In the ${ }^{1} \mathrm{H}$ NMR spectrum for the anhydride (3), there were characteristic signals of a singlet assigned to the two hydrogens of the $\mathrm{CH}_{2}$ of the methylenedioxy group at $\delta_{\mathrm{H}} 5.87$, multiple signals for two hydrogens, one at $\delta_{\mathrm{H}} 2.54$ and one at $\delta_{\mathrm{H}} 2.46$ of the methylene hydrogens, $\mathrm{CH}_{2}$, a doublet at $\delta_{\mathrm{H}} 1.02$ referring to three hydrogens of the $\mathrm{CH}_{3}$ group. In the ${ }^{13} \mathrm{C}$ NMR spectrum, we observed two characteristic signals of the carbonyl of the anhydride (3) around $\delta_{\mathrm{C}} 173.61$ and $\delta_{\mathrm{C}} 173.53$. The carbon signal for the methylenedioxy group appeared at $\delta_{\mathrm{C}} 100.67$. A signal at $\delta \mathrm{c} 19.05$ was assigned to the carbon of $\mathrm{CH}_{3}$.

In the third and final step, the cyclic imides (4a-4i) and (4j) were obtained in 56-63\% yields from the reaction of the anhydride (3) with the substituted aromatic amines and/or glycine under reflux for $3 \mathrm{~h}$, using glacial acetic acid as the solvent (Scheme 1).The purity of the compounds was checked by examining the melting point range.

The structures of the cyclic imides derived from safrole were confirmed by IR and ${ }^{1} \mathrm{H}$ and ${ }^{13} \mathrm{C}$ NMR, including the two-dimensional techniques ${ }^{1} \mathrm{H}-{ }^{1} \mathrm{H}$ correlated spectroscopy (COSY) and ${ }^{1} \mathrm{H}^{-13} \mathrm{C}$ heteronuclear multiple quantum coherence (HMQC) and heteronuclear multiple bond correlation (HMBC). Analyzing the NMR spectrum of compound $\mathbf{4 h}$, signals were observed in the region of the aromatic hydrogens between $\delta_{\mathrm{H}}$ 7.54-6.73 referring to the 6 aromatic hydrogens. In the two-dimensional analyses $\left({ }^{1} \mathrm{H}-{ }^{1} \mathrm{H}\right.$ COSY $)$, the spectrum showed the presence of
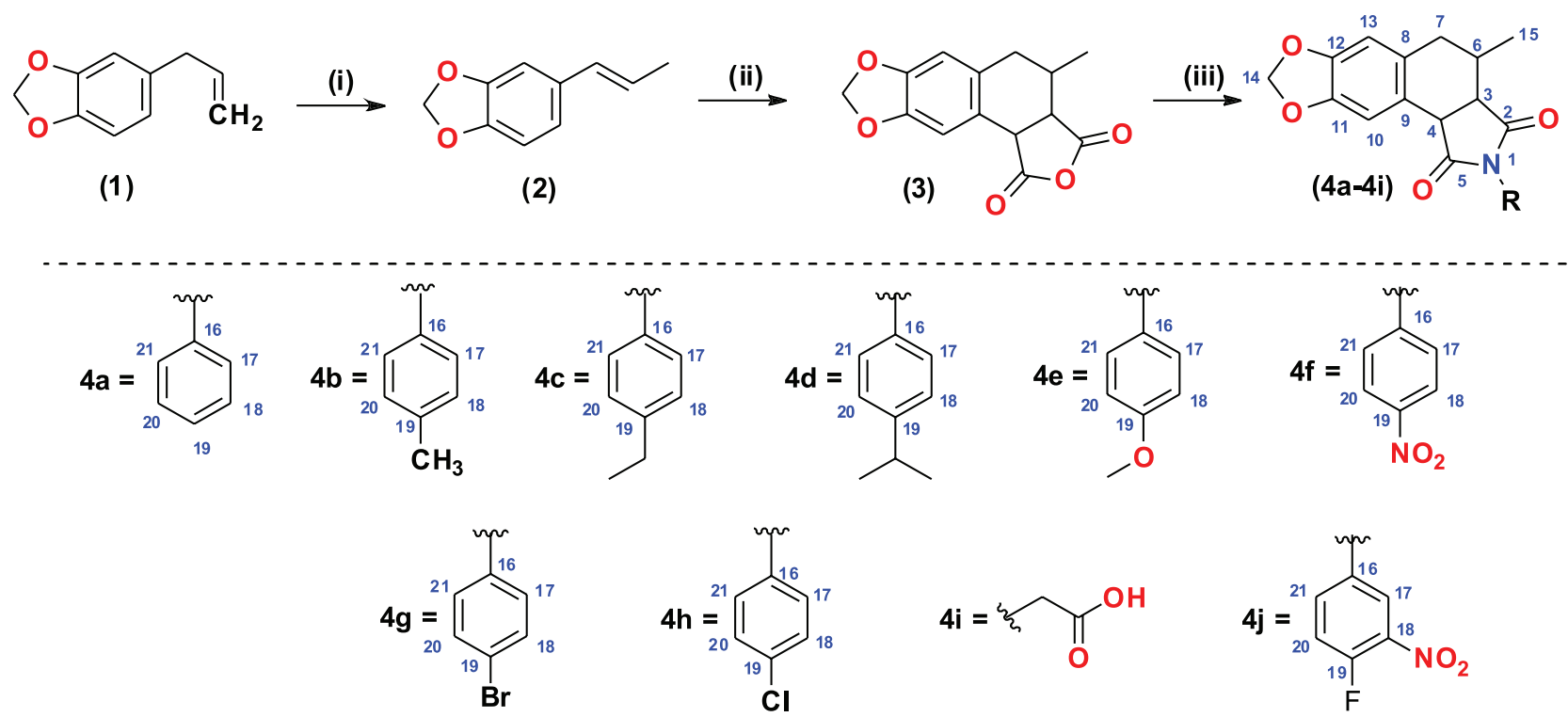

Scheme 1. Synthetic route for the target molecules. Reagents and conditions: (i) $3 \mathrm{M} \mathrm{KOH,} n$-BuOH, reflux, $6 \mathrm{~h}$; (ii) maleic anhydride, $o$-xylene, reflux, $4 \mathrm{~h}$; (iii) aromatic amine/glycine, acetic acid, reflux, $3 \mathrm{~h}$ yield 56-63\%. 
four important correlations coupled to each other by aliphatic hydrogens: $\mathrm{H}-4$ at $\delta_{\mathrm{H}} 4.24$ coupled to and $\mathrm{H}-3$ at $\delta_{\mathrm{H}} 3.49, \mathrm{H}-3$ coupled to $\mathrm{H}-6$ at $\delta_{\mathrm{H}} 2.28$ and finally $\mathrm{H}-6$ coupled to the hydrogens $\mathrm{H}-7$ at $\delta_{\mathrm{H}} 2.72$ and $\delta_{\mathrm{H}} 2.46$ and $\mathrm{H}-15$ at $\delta_{\mathrm{H}}$ 1.08. Also in this spectrum, we could discern two more correlations between aromatic hydrogens in the para position with respect to the chlorine, between $\mathrm{H}-17$ at $\delta_{\mathrm{H}} 7.27$ and $\mathrm{H}-18$ at $\delta_{\mathrm{H}} 7.54$, similarly observed between the hydrogens $\mathrm{H}-21$ and $\mathrm{H}-20$, respectively, of system described as AA'BB'. In the two-dimensional direct correlation spectrum $\left({ }^{1} \mathrm{H}-{ }^{13} \mathrm{C}\right.$ HMQC), we observed correlations between: the signal at $\delta_{\mathrm{H}} 1.08$ referring to the methyl hydrogen $\mathrm{H}-15$ and the $\mathrm{C}-15$ signal at $\delta_{\mathrm{C}} 16.25$; the $\mathrm{H}-7 \mathrm{a}$ and $\mathrm{H}-7 \mathrm{~b}$ signals respectively at $\delta_{\mathrm{H}} 2.72$ and $\delta_{\mathrm{H}} 2.46$ and the C-7 signal at $\delta_{\mathrm{C}} 34.59$; and the $\mathrm{H}-6$ signal at $\delta_{\mathrm{H}} 2.28$ and the C-6 signal at $\delta_{\mathrm{C}} 29.63$.

According to the analyses of the compounds, $4 \mathbf{h}$ and the imides (4a-4i and $\mathbf{4 j}$ ) had a doublet for three hydrogens of the methyl group (H-5) with displacements ranging $\delta_{\mathrm{H}}$ 1.10-1.6 and a multiplet for the methylene hydrogens $\mathrm{H}-7 \mathrm{a}$ and $\mathrm{H}-7 \mathrm{~b}$ varying $\delta_{\mathrm{H}}$ 2.74-2.72 and $\delta_{\mathrm{H}} 2.46-2.43$, respectively. There was a double doublet for $\mathrm{H}-4$ in the range of $\delta_{\mathrm{H}}$ 4.28-4.22 along with a double doublet for a hydrogen of $\mathrm{H}-3$ in the range of $\delta_{\mathrm{H}} 3.52-3.46$. Signals of the hydrogens of the aromatic ring appeared at $\delta_{\mathrm{H}}$ 7.92-7.67.

In compounds $\mathbf{4 a - 4 j}$, the signals for the aromatic hydrogens were in the range of 7.54-6.73. In the spectrum of $\mathbf{4 b}$, a singlet for 3 hydrogens appeared at $\delta_{\mathrm{H}} 2.33$, referring to the methyl group. In the spectrum of $\mathbf{4 c}$, the ethyl group was characterized by a triplet for 3 hydrogens at $\delta_{\mathrm{H}} 1.19$ and a quartet for 2 hydrogens at $\delta_{\mathrm{H}} 2$.63. In the spectrum of $\mathbf{4 d}$, there was a doublet for 6 hydrogens at $\delta_{\mathrm{H}} 1.21$ and one septet for 1 hydrogen at $\delta_{\mathrm{H}} 2.92$ for the isopropyl group. In the spectrum of $\mathbf{4 e}$, we observed a singlet for 3 hydrogens at $\delta_{\mathrm{H}} 3.78$ referring to the methoxy group. In the spectrum of compound $\mathbf{4 i}$, the signal for methylene hydrogen was seen at $\delta_{\mathrm{H}} 3.52$.

All 4a-4j imides displayed two characteristic signals attributed to carbonyls (C-2 and C-5) in the range of $\delta_{\mathrm{C}}$ 177.16-175.91. In the HMBC spectrum of $\mathbf{4 h}$ it was possible to attribute the displacements of the referred carbonyls in the compound from the couplings between ${ }^{13} \mathrm{C}$ and ${ }^{1} \mathrm{H}$ far two and three links. The methane hydrogens $(\mathrm{H}-4)$ at $\delta_{\mathrm{H}} 4.24$ were coupled with carbons C-2, C-3, C-5, C-6, C-8, C-9 and C-10 at $\delta_{\mathrm{C}} 176.68,43.76,176.06$, $29.63,129.73,122.17$ and 109.22, respectively, and $\mathrm{H}-3$ of methine at $\delta_{\mathrm{H}} 3.49$ with carbons C-2, C-4, C-5, C-6, C-7, C-9 and C-10 at $\delta_{\mathrm{C}} 176.68,43.06,176.06,29.63,34.59$, 122.17 and 109.22 , respectively.

Compounds $\mathbf{4 a - 4 i}$ showed five signals in the aliphatic region being: one in the range of $\delta_{\mathrm{C}} 16.62-16.22$ referring to a methyl carbon (C-15), one in the range of $\delta_{\mathrm{C}} 30.17-29.63$ attributed to a methine carbon (C-6), one in the range of $\delta_{\mathrm{C}}$ 54.70-54.56 referring to methylene carbon $(\mathrm{C}-7)$, one around $\delta_{\mathrm{C}} 43.62-42.90$ referring to a methine carbon $(\mathrm{C}-4)$ and one in the range of $\delta_{\mathrm{C}} 43.95-43.77$ assigned to a methine carbon (C-3). We observed in all compounds a signal for the carbon of the methylenedioxy group in the range of $\delta_{\mathrm{C}} 100.88-100.48$ and a signal for the aromatic carbons in the range of $\delta_{\mathrm{C}} 146.40-108.60$.

In the spectrum of $\mathbf{4 b}$, an additional signal in the aliphatic region at $\delta_{\mathrm{C}} 21.19$, attributed to the carbon of the methyl group, was observed. In the spectrum of $\mathbf{4 c}$, we found two additional signals in the aliphatic region: one at $\delta_{\mathrm{C}} 27.84$ and another at $\delta_{\mathrm{C}} 15.53$ attributed to the carbons of the ethyl group. In the spectrum of $\mathbf{4 d}$, there were two additional signals: one at $\delta_{\mathrm{C}} 33.18$ and another at $\delta_{\mathrm{C}} 23.77$, attributed to the carbons of the isopropyl group. In the spectrum of compound $\mathbf{4 e}$, an additional signal was observed at $\delta_{\mathrm{C}} 55.43$, attributed to the methoxy group carbon. In the spectrum of $\mathbf{4 i}$, we found an additional signal at $\delta_{\mathrm{C}} 39.12$, attributed to the methylene carbon, and one at $\delta_{\mathrm{C}} 166.77$ referring to the carbonyl carbon of the carboxylic acid group.

Specifically for compounds $\mathbf{4 a}$ and $\mathbf{4 j}$, the melting point and NMR spectroscopic ${ }^{1} \mathrm{H}$ and ${ }^{13} \mathrm{C}$ studies, corroborate with results from studies of our research group previously obtained. ${ }^{17}$

In the IR spectrum, all compounds (4a-4j) exhibited axial deformation of $\mathrm{C}=\mathrm{O}$ of the imide around $1700 \mathrm{~cm}^{-1}$. These absorptions are consistent with the absorption values of the 5-membered heterocyclic imides. ${ }^{18}$ All compounds (4a-4j) showed the stretching absorption bands of $\mathrm{C}-\mathrm{H}$ $\mathrm{sp}^{2}$ of the aromatic rings ranging $3207-3053 \mathrm{~cm}^{-1}$. The $\mathrm{C}=\mathrm{C}$ stretching bands of the aromatic rings ranged $1600-1585 \mathrm{~cm}^{-1}$. Compound $\mathbf{4 f}$ containing the nitro group showed as characteristics two absorption bands, around $1529-1510 \mathrm{~cm}^{-1}$ and $1362-1342 \mathrm{~cm}^{-1}$. For the halogencontaining compounds at the para position of the aromatic ring, $\mathbf{4 g}$ and $\mathbf{4 h}$, the absorption bands were observed around 1186 and $1045 \mathrm{~cm}^{-1}$, respectively.

\section{Theoretical chemistry study}

Prediction of NMR spectra is an important step for studying new materials. Such results can be reached by adopting different theories and protocols. ${ }^{19}$

In recent years, we are witnessing a growing interest in using NMR calculations to help elucidate stereochemistry and/or confirm the structure of new synthesized molecules. ${ }^{20}$ In line with that, Smith and Goodman ${ }^{21,22}$ presented an approach aiming to help assigning stereochemistry of 
organic molecules by using a combination of calculated and experimental ${ }^{13} \mathrm{C}$ and ${ }^{1} \mathrm{H}$ NMR shifts data. They termed such approach as DP4.

In short, DP4 approach requires calculated NMR chemical shift data for all possible diastereomers and applies a statistical procedure to decide which diastereomers are present in the mixture. In their publications, ${ }^{21,22}$ the authors have successfully tested DP4 in assigning stereochemistry for several organic molecules and natural products. Recently, DP4 approach has been expanding in many ways. Now, there is an automatized workflow for using DP4, where the user is able to use it as a python application to analyze the output of several molecular modelling packages. ${ }^{23}$

In this part of our study, we have carried out NMR shift calculations in order to shed light on the stereochemistry of products $\mathbf{4 a - 4 j}$. For this, we have selected only one compound, $\mathbf{4 j}$, to do such theoretical assessment. The reason why we have selected $\mathbf{4} \mathbf{j}$ was because it has same shape of all synthesized molecules, its substituents do not generate new chiral carbon atoms and $\mathbf{4} \mathbf{j}$ has the most electronegative substituents connected to the aromatic ring. Compound $\mathbf{4} \mathbf{j}$ has three chiral carbon atoms as shown in the Figure 1, totalizing $2^{3}$ stereoisomers.

In our theoretical study for help assigning stereochemistry of $\mathbf{4 j}$, we have adopted the same protocol described in the study performed by Ermanis et al. ${ }^{24}$ Such protocol uses different theoretical methods to fit experimental NMR data with optimal performance. In the following, we describe the main parts of our theoretical methodology.

Our NMR calculations started with extraction of Cartesian coordinates for the eight stereoisomers of $\mathbf{4 j}$. We got them by using Marvin Sketch software. ${ }^{25}$

After that, we carried out full ground state geometry optimizations in dimethyl sulfoxide (DMSO) (polarizable continuum model (PMC) implicit solvent model) for the eight stereoisomers of $\mathbf{4 j}$ by using Gaussian09.C01 software. ${ }^{26}$ For these calculations, we used B3LYP functional with cc-pVTZ basis set. The molecular structures of stereoisomers of $\mathbf{4} \mathbf{j}$ were attested to be minima on their respective potential energy surfaces using a vibrational frequency analysis, wherein the real minimum molecular structure must exhibit positive values for all frequencies. An additional important point was that all stereoisomers kept their configurations after geometry optimization.

${ }^{13} \mathrm{C}$ and ${ }^{1} \mathrm{H}$ NMR chemical shifts calculations were performed using GIAO method. For these calculations, we used mPW1PW91 DFT functional and the same basis set, as has been recommended in the protocol described in literature. ${ }^{22}$ NMR calculations were performed in DMSO solvent too.
The final step of our theoretical methodology was the calculation of free energies of all stereoisomers. We followed the guidance presented in the study performed by Ermanis et al. ${ }^{24}$ and carried out these calculations using M06-2X DFT functional with the same basis set, at temperature $298 \mathrm{~K}$ and $1.0 \mathrm{~atm}$. Free energies of all eight isomers of $\mathbf{4} \mathbf{j}$ were also calculated considering PCM implicit model to represent DMSO solvent. We used free energies to compare the most stable isomer with stereoisomers pointed out by DP4 as being the most present in synthesized mixture of $\mathbf{4} \mathbf{j}$.

Now, after having all these data in our hands, we use the DP4 applet to try to know the stereoisomers that are present in the synthesized products by using experimental and calculated data chemical shifts.

First, theoretical ${ }^{13} \mathrm{C}$ and ${ }^{1} \mathrm{H}$ NMR chemical shifts presented a good correlation with the experimental data (about 99\% for all cases), except for carbon bonded a nitro group, as can be seen in Figure 1, which presented a mean absolute error of $14 \mathrm{ppm}$. We believe that, probably, this large error was due to deactivating effect of nitro group that tend to withdraw the electronic density. Anyway, the magnitude of this error is in agreement with results obtained by Cheeseman et al. ${ }^{27}$

Table 1 shows results for DP4 probabilities and calculated relative free energies $\left(\Delta \mathrm{G}_{4 \mathrm{j}(\mathrm{x})-4 \mathrm{j}(2)}\right.$, where $\mathrm{x}$ is one of eight isomers of $\mathbf{4 j}$ ). From DP4 probabilities, we can see that isomers $4 \mathbf{j}(1)$ and $4 \mathbf{j}(2)$ are the most likely isomers in the mixture that was synthesized. This result is also in agreement with the calculated relative free energies in DMSO. In Table 1, we can see that $\mathbf{4 j}(2)$ is the most stable isomer of $\mathbf{4 j}$ and isomer $\mathbf{4 j}(1)$ is only $0.026 \mathrm{~kJ} \mathrm{~mol}^{-1}$ higher. All others $\mathbf{4 j}$ 's isomers present relative free energies larger than $6.0 \mathrm{~kJ} \mathrm{~mol}^{-1}$ in comparison with $4 \mathbf{j}(2)$, larger values to be present in synthesized mixture (Figure 2).

In the Supplementary Information (SI) section, we present the calculated ${ }^{13} \mathrm{C}$ and ${ }^{1} \mathrm{H}$ NMR chemical shifts for all stereoisomers of $\mathbf{4 j}$ (Tables S1-S8). There are also presented the ground state geometries for all eight stereoisomers of $\mathbf{4 j}$ (Tables S9-S16).

\section{Drug likeness of cyclic imides}

Screening in silico of pharmacokinetic parameters to predict whether a particular compound will become a drug candidate is of utmost importance to current scientific research. The most widespread study was that of the pioneers Lipinski et al., ${ }^{28}$ who showed a relationship between pharmacokinetic and physicochemical parameters, indicating that a particular molecule will have high potential as a drug if it shows high 
<smiles></smiles>

$4 j(1)$<smiles>C[C@H]1C(=O)CCc2cc3c(cc21)OCO3</smiles>

$4 j(3)$<smiles></smiles>

$4 j(5)$<smiles>C[C@H]1C(=O)CCc2cc3c(cc21)OCO3</smiles>

$4 j(7)$<smiles>C[C@H]1c2cc3c(cc2C(=O)N1[O-])[C@@H](C)C(=O)N(c1ccc(F)c([N+](=O)[O-])c1)CC3</smiles>

4j(2)<smiles>O=C1[C@@H]2c3cc4c(cc3CC[C@H]2C(=O)N1c1ccc(F)c([N+](=O)[O-])c1)OCO4</smiles>

4j(4)<smiles></smiles>

4j(6)<smiles></smiles>

$4 j(8)$

Figure 1. Stereoisomers from structure $\mathbf{4} \mathbf{j}$ with their stereocenters in red, blue and green.

Table 1. DP4 probabilities obtained from ${ }^{13} \mathrm{C}$ and ${ }^{1} \mathrm{H}$ theoretical and experimental data, and relative free energies, $\Delta \mathrm{G}_{4 \mathbf{j}(\mathrm{x})-4 \mathrm{j}(2)}$, calculated using M06-2X/cc-pVTZ method, to all isomers of $\mathbf{4 j}$, for end, the chiral center to the respective color of carbons red, blue and green shown in Figure 1

\begin{tabular}{lccc}
\hline $\begin{array}{l}\text { Stereoisomers, } \\
\mathbf{4 j}(\mathrm{x})\end{array}$ & $\begin{array}{c}\text { DP4 probability / } \\
\%\end{array}$ & $\begin{array}{c}\Delta \mathrm{G}_{4 \mathbf{j}(\mathrm{x}) \mathbf{4} \mathbf{j}(2)} / \\
\left(\mathrm{kJ} \mathrm{mol}^{-1}\right)\end{array}$ & Chiral centers \\
\hline 1 & 49.9 & 0.026 & $S R R$ \\
2 & 50.1 & 0.000 & $R S S$ \\
3 & 0.0 & 6.432 & $R R R$ \\
4 & 0.0 & 34.368 & $S S R$ \\
5 & 0.0 & 6.432 & $S S S$ \\
6 & 0.0 & 30.797 & $S R S$ \\
7 & 0.0 & 34.342 & $R R S$ \\
8 & 0.0 & 32.110 & $R S R$ \\
\hline
\end{tabular}

resemblance to existing drugs, known as drug-likeness. Considering these factors, Lipinski et al. ${ }^{28}$ proposed a set of rules that evaluate the oral bioavailability of new molecules

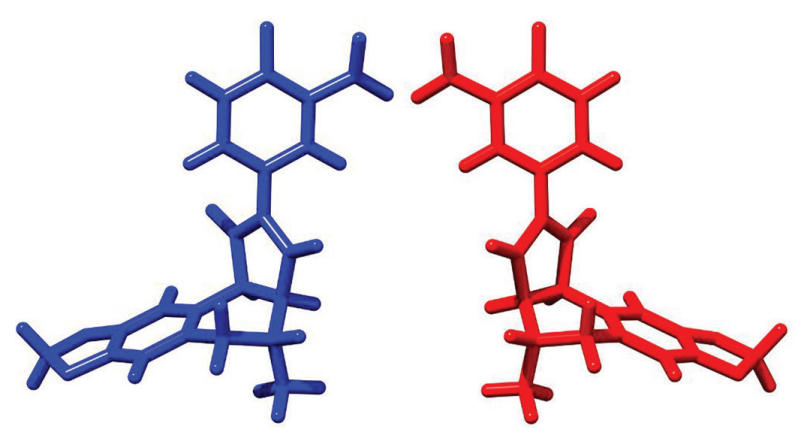

Figure 2. The two isomers most likely present in synthesized mixture, $4 \mathbf{j}(1)$ (red) and $4 \mathbf{j}(2)$ (blue). 
with therapeutic potential, known as the Lipinski's rule of five, and that considers four parameters (whose values are multiples of 5) that identify drugs with possible absorption and permeability problems. These parameters are molecular weight $\leq 500 \mathrm{~g} \mathrm{~mol}^{-1}$, milog $\mathrm{P} \leq 5$, number of hydrogen bond acceptors of $\leq 10$ (counted on the basis of $\mathrm{N}$ or $\mathrm{O}$ atoms in the molecule), and number of hydrogen bond donors $\leq 5$ (represented as a function of the $\mathrm{NH}$ or $\mathrm{OH}$ groups in the molecule).

In this present work, we decided to investigate the potential of the compounds $\mathbf{4} \mathbf{a}-\mathbf{4} \mathbf{j}$ as potential new drug candidates through the in silico approach of the Lipinski parameters (milog P, molecular weight, number of hydrogen bond acceptors and hydrogen bond donors), and also the topological polar surface area (TPSA), aqueous solubility $(\log \mathrm{S})$, drug-likeness and drug score. Accordingly, we used the programs available online, namely Molinspiration, ${ }^{29}$ Swiss ADME ${ }^{30}$ and Osiris Property Explorer. ${ }^{31}$ The percentage of absorption (ABS) was determined by the equation $\operatorname{ABS}(\%)=109-(0.345 \times$ TPSA $)$ according to Zhao et al..$^{32}$ The calculated values for the studies are presented in Table 2.

The theoretically determined physico-chemical properties of compounds $\mathbf{4 a - 4 j}$ are shown in Table 2 and indicate that all compounds satisfied the Lipinski's rule of five with zero violation order, thus suggesting that such compounds would have no problems with oral bioavailability. In general, all compounds had a milog P less than 5 , where the lowest value was for $4 \mathbf{i}$ with -0.25 and the highest value for $\mathbf{4 d}$ with $4.63 . \log \mathrm{P}$ is an important parameter in the design of a drug candidate molecule, as it is associated with the hydrophobicity of the molecule in the drug and influences the ability to cross cell membranes. However, substances that are too hydrophobic are usually more toxic, as they stay in the body longer. Therefore, the synthesized molecules $\mathbf{4 a - 4 i}$ met the requirements for the Lipinski log P parameter. Another important parameter is the molecular mass of the compound. Compounds that have higher molecular weights are bulkier and this can interfere in absorption and in their pharmacological interactions. The molecular weights of compounds $\mathbf{4 a - 4 i}$ showed values between 317.30-398.35 $\mathrm{g} \mathrm{mol}^{-1}$. The results of hydrogen acceptors and donors shown in Table 2, met the parameters of the rule of 5 , where the number of hydrogen donors must be $\leq 5$ and hydrogen acceptors must be $\leq 10$. All compounds showed TPSA less than $140 \AA^{2}$, which indicates good cell membrane permeability. ${ }^{33}$ The absorption percentage showed good absorption of the compounds, the lowest value being for $\mathbf{4 f}$ and $\mathbf{4 j}$ with $73.92 \%$ and the highest values being for $\mathbf{4 a}, \mathbf{4 b}, \mathbf{4 c}, \mathbf{4 d}, \mathbf{4} \mathbf{g}$ and $\mathbf{4 h}$ with $89.73 \%$ (Table 2).

Water solubility is an important characteristic for the absorption and distribution of drugs in the body. The values of $\log \mathrm{S}$ represent the solubility according to the following scale: insoluble $<-10<$ poorly soluble $<-6<$ moderately soluble $<-4<$ soluble $<-2<$ very soluble $<0<$ highly soluble. ${ }^{34}$ The $\log \mathrm{S}$ values of compounds $4 \mathbf{a}-4 \mathbf{i}$ were between -2.57 and -5.06 , where $4 \mathbf{i}$ was considered soluble and $\mathbf{4 a - 4 j}$ moderately soluble.

Drug-likeness is an important index that indicates whether a particular compound has similarity with commercially available drugs, where a positive score indicates that a compound will be a good drug candidate. Table 2 shows that only compounds $\mathbf{4 a}, \mathbf{4 b}, \mathbf{4 c}, \mathbf{4 d}, \mathbf{4 e}, \mathbf{4 g}$ and 4h had positive values for drug-likeness, thus indicating that

Table 2. In silico studies evaluating Lipinski's rule of five for compounds $\mathbf{4 a - 4 j}$

\begin{tabular}{|c|c|c|c|c|c|c|c|c|c|c|c|}
\hline \multirow{2}{*}{ Compound } & \multicolumn{5}{|c|}{ Lipinski parameter } & \multirow{2}{*}{$\begin{array}{c}\text { TPSA / } \\
\AA^{2}\end{array}$} & \multirow{2}{*}{$\begin{array}{c}\mathrm{ABS} / \\
\%\end{array}$} & \multirow{2}{*}{$\log S$} & \multirow{2}{*}{ Class } & \multirow{2}{*}{$\begin{array}{l}\text { Drug- } \\
\text { likeness }\end{array}$} & \multirow{2}{*}{ Drug score } \\
\hline & MW & HBD & HBA & milog $\mathrm{P}$ & $\mathrm{nV}$ & & & & & & \\
\hline $4 a$ & 335.36 & 0 & 5 & 3.11 & 0 & 55.85 & 89.73 & -4.15 & moderately & 4.65 & 0.65 \\
\hline $4 b$ & 349.39 & 0 & 5 & 3.56 & 0 & 55.85 & 89.73 & -4.45 & moderately & 2.61 & 0.57 \\
\hline $4 c$ & 363.41 & 0 & 5 & 4.03 & 0 & 55.85 & 89.73 & -4.73 & moderately & 3.63 & 0.43 \\
\hline $4 d$ & 377.44 & 0 & 5 & 4.63 & 0 & 55.85 & 89.73 & -5.01 & moderately & 1.37 & 0.42 \\
\hline $4 e$ & 365.38 & 0 & 6 & 3.17 & 0 & 65.08 & 86.54 & -4.22 & moderately & 2.58 & 0.62 \\
\hline $4 f$ & 380.36 & 0 & 8 & 3.07 & 0 & 101.67 & 73.92 & -4.21 & moderately & -7.36 & 0.31 \\
\hline $4 g$ & 414.25 & 0 & 5 & 3.92 & 0 & 55.85 & 89.73 & -5.06 & moderately & 1.81 & 0.45 \\
\hline $4 h$ & 369.80 & 0 & 5 & 3.79 & 0 & 55.85 & 89.73 & -4.74 & moderately & 4.45 & 0.52 \\
\hline $4 i$ & 317.30 & 1 & 7 & -0.25 & 0 & 93.15 & 76.86 & -2.57 & soluble & -0.88 & 0.58 \\
\hline $4 j$ & 398.35 & 0 & 8 & 3.16 & 0 & 101.67 & 73.92 & -4.37 & moderately & -7.56 & 0.28 \\
\hline
\end{tabular}

Physicochemical properties: MW: molecular weight; HBD: hydrogen bonding donor; HBA: hydrogen bonding acceptor; milog P: octanol/water partition coefficient based on Molinspiration milog P model; nV: number of violations; TPSA: total polar surface area; ABS: adsorption percentage; log S: coefficient of solubility determined by the ESOL method calculated on SwissADME; class: insoluble $<-10<$ poorly $<-6<$ moderately $<-4<$ soluble $<-2<$ very $<0<$ highly. 
the derivatives investigated have moieties and/or physicochemical properties as most commercial drugs.

The drug score value considers drug-likeness, lipophilicity, solubility, molecular weight and toxicity risks together, ranging from 0.0 to 1.0 and can be used to predict the overall ability of a given compound to be a new drug candidate. The drug score values obtained varied between 0.31 and 0.65 , with the highest value found for 4a, so the imides synthesized can be considered potential drug candidates.

\section{Biological studies}

\section{Antifungal activity}

The in vitro antifungal activity of the compounds $\mathbf{4 a} \mathbf{a} \mathbf{4 j}$ was evaluated by the microdilution method with six pathogenic fungal strains, Cryptococcus gattii INCQS-40113, Cryptococcus neoformans LM-260, Cryptococcus neoformans FCF-119, Candida parapsilosis ATCC-22019, Candida krusei LM-656 and Candida albicans ATCC-76645, using amphotericin B as the standard drug (Table 3).

Sortino et al. ${ }^{5}$ showed that maleimides substituted in aqueous medium showed antifungal activities on Candida species with minimum inhibitory concentration (MIC) of 0.48-3.9 $\mu \mathrm{g} \mathrm{mL}^{-1}\left(0.0027-0.022 \mu \mathrm{mol} \mathrm{mL}^{-1}\right)$. The results encouraged us to carry out studies of the imidic compounds derived from safrole as antifungal agents.
Of the ten compounds tested, $\mathbf{4 a}, \mathbf{4 d}$ and $\mathbf{4 f}$ showed no antifungal activity against the test strains used. Compound 4b showed $60 \%$ inhibition and exhibited activity against the strains $C$. neoformans FCF-119, C. parapsilosis ATCC-22019 and C. krusei LM-656

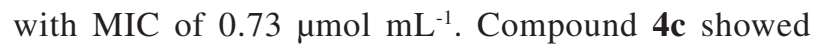
$80 \%$ inhibition and good activity against the strains C. neoformans FCF-119, C. parapsilosis ATCC-22019 and C. krusei LM-656 with a MIC ranging 0.70-1.40 $\mu \mathrm{mol} \mathrm{mL} \mathrm{mL}^{-1}$, and it showed activity against $C$. neoformans LM-260 with a MIC of $2.81 \mu \mathrm{mol} \mathrm{mL} \mathrm{mL}^{-1}$. Compound $4 \mathrm{e}$ showed $100 \%$ inhibition and good activity against $C$. neoformans LM-260 and $C$. neoformans FCF-119 with a MIC of $1.40 \mu \mathrm{mol} \mathrm{mL} \mathrm{mL}^{-1}$, and it exhibited activity against $C$. gattii INCQS-40113, C. parapsilosis ATCC-22019 and C. krusei LM-656 with a MIC of $2.80 \mu \mathrm{mol} \mathrm{mL} \mathrm{m}^{-1}$. Compound $\mathbf{4 g}$ showed $100 \%$ inhibition and exhibited activity against $C$. neoformans LM-260, C. neoformans FCF-119 and C. parapsilosis ATCC-22019 with a MIC of $1.23 \mu \mathrm{mol} \mathrm{mL}{ }^{-1}$, and it showed activity against $C$. gattii INCQS-40113 and $C$. kruse $i$ LM656 with a MIC of $2.47 \mu \mathrm{mol} \mathrm{mL}^{-1}$.

Compound 4 h showed $80 \%$ inhibition and exhibited activity against $C$. gattii INCQS-40113, C. neoformans LM-260 and $C$. neoformans FCF-119 with MIC ranging $0.17-1.38 \mu \mathrm{mol} \mathrm{mL} \mathrm{m}^{-1}$, and it showed activity against $C$. krusei LM-656 with a MIC of $2.76 \mu \mathrm{mol} \mathrm{mL}^{-1}$. Compound $4 \mathbf{i}$ showed $100 \%$ inhibition and exhibited activity against C. gattii INCQS-40113 and C. neoformans FCF-119 with

Table 3. Minimum inhibitory concentration (MIC) of imides $\mathbf{4 a - 4 j}$

\begin{tabular}{|c|c|c|c|c|c|c|}
\hline \multirow{3}{*}{ Compound } & \multicolumn{6}{|c|}{$\mathrm{MIC} /\left(\mu \mathrm{mol} \mathrm{mL}^{-1}\right)$} \\
\hline & \multicolumn{6}{|c|}{ Fungal strains } \\
\hline & $\begin{array}{c}\text { Cryptococcus gattii } \\
\text { INCQS-40113 }\end{array}$ & $\begin{array}{c}\text { Cryptococcus } \\
\text { neoformans } \\
\text { LM-260 }\end{array}$ & $\begin{array}{c}\text { Cryptococcus } \\
\text { neoformans } \\
\text { FCF-119 }\end{array}$ & $\begin{array}{c}\text { Candida parapsilosis } \\
\text { ATCC-22019 }\end{array}$ & $\begin{array}{c}\text { Candida krusei } \\
\text { LM-656 }\end{array}$ & $\begin{array}{c}\text { Candida albicans } \\
\text { ATCC-76645 }\end{array}$ \\
\hline $4 a$ & + & + & + & + & + & + \\
\hline $4 b$ & + & + & 0.73 & 0.73 & 0.73 & 0.73 \\
\hline $4 c$ & + & 2.81 & 0.70 & 1.40 & 0.70 & 1.40 \\
\hline $4 d$ & + & + & + & + & + & + \\
\hline $4 e$ & 2.80 & 1.40 & 1.40 & 2.80 & 2.80 & 1.40 \\
\hline $4 f$ & + & + & + & + & + & + \\
\hline $4 g$ & 2.47 & 1.23 & 1.23 & 1.23 & 2.47 & 1.23 \\
\hline $4 h$ & 0.17 & 1.38 & 1.38 & + & 2.76 & 1.38 \\
\hline $4 i$ & 1.61 & 3.22 & 1.61 & 3.22 & 3.22 & 3.22 \\
\hline $4 \mathbf{j}$ & 1.28 & 1.28 & 1.28 & 1.28 & 1.28 & 1.28 \\
\hline $\begin{array}{l}\text { Culture medium } \\
\text { control }\end{array}$ & - & - & - & - & - & - \\
\hline Amphotericin B & 0.034 & 0.034 & 0.034 & 0.034 & 0.034 & 0.034 \\
\hline
\end{tabular}

-: there was no growth of the microorganism; +: growth of the microorganism. 
a MIC of $1.61 \mu \mathrm{mol} \mathrm{mL} \mathrm{mL}^{-1}$, and it exhibited activity against the C. neoformans LM-260, C. parapsilosis ATCC-22019 and $C$. krusei LM-656 with a MIC of $3.22 \mu \mathrm{mol} \mathrm{mL} \mathrm{m}^{-1}$. The compound $\mathbf{4 j}$ exhibited antifungal activity with MIC $1.28 \mu \mathrm{mol} \mathrm{mL}^{-1}$ for all strains tested.

\section{Conclusions}

In this study, we synthesized nine cyclic imides using 3 steps and getting yields between 60 and $80 \%$. Their structures were confirmed by the spectroscopic techniques of IR and ${ }^{1} \mathrm{H}$ and ${ }^{13} \mathrm{C}$ NMR, including two-dimensional NMR techniques ${ }^{1} \mathrm{H}-{ }^{1} \mathrm{H}-\mathrm{COSY}$ and ${ }^{1} \mathrm{H}-{ }^{13} \mathrm{C}$ HSQC and HMBC. All compounds were evaluated for antifungal activity in vitro against different strains, and only three of the nine compounds did not show an inhibitory effect against the strains. The most active compounds were $\mathbf{4 h}$ against C. gattii INCQS-40113 (MIC of $0.17 \mu \mathrm{mol} \mathrm{mL}^{-1}$ ), $4 \mathbf{b}$ against C. neoformans FCF-119, C. parapsilosis ATCC-22019 and C. krusei LM-656 (MIC of $0.73 \mu \mathrm{mol} \mathrm{mL} \mathrm{m}^{-1}$ ) and $\mathbf{4 c}$ against C. neoformans FCF-119 and C. krusei LM-656 (MIC of $0.70 \mu \mathrm{mol} \mathrm{mL} \mathrm{m}^{-1}$ ). The compound $\mathbf{4 j}$ exhibited antifungal activity with MIC $1.28 \mu \mathrm{mol} \mathrm{mL}{ }^{-1}$ for all strains tested. The in silico study showed that none of compounds violated Lipinski's rule of five and have a desirable profile for being new drug candidates. Using calculated and experimental ${ }^{13} \mathrm{C}$ and ${ }^{1} \mathrm{H}$ NMR chemical shifts data we have assigned the composition of the synthesized mixture of $\mathbf{4} \mathbf{j}$ compound, that is formed by the stereoisomers $4 \mathbf{j}(1)(S R R)$ and $4 \mathbf{j}(2)$ $(R S S)$, see Figure 1. These results can suggest that others synthesized structures, $\mathbf{4} \mathbf{a}-\mathbf{4} \mathbf{j}$, also can have the same stereochemistry.

\section{Experimental}

\section{Chemistry}

All reagents and solvents were purchased from commercial sources (Sigma-Aldrich, São Paulo, Brazil) and used without a further purification. The progress of the reactions was monitored by thin layer chromatography (TLC) on silica gel plates. The spectra (IR) were obtained on a Shimadzu model IRPrestige-21 FTIR spectrometer, using $\mathrm{KBr}$ pellets. NMR spectroscopic data were recorded with a Bruker Avance 400 instrument. ${ }^{1} \mathrm{H}$ NMR spectroscopic data were recorded in DMSO- $d_{6}$ at $400 \mathrm{MHz}$ using the residual non-deuterated solvent as an internal standard $\left(\delta_{\mathrm{H}} 2.50 \mathrm{ppm}\right) .{ }^{13} \mathrm{C}$ NMR spectra were recorded in DMSO- $d_{6}$ at $101 \mathrm{MHz}$ using the deuterated solvent as an internal standard $\left(\delta_{\mathrm{C}} 39.5 \mathrm{ppm}\right)$, and tetramethylsilane (TMS) was used for the internal standard. Chemical shifts $(\delta)$ were measured in parts per million ( $\mathrm{ppm})$, and the coupling constants $(J)$ in hertz $(\mathrm{Hz})$. HRMS analysis was obtained with time-of-flight (TOF) mass spectrometer (microTOFII-Bruker) instrument using electron impact ionization (EI) and reported as $\mathrm{m} / \mathrm{z}$ (relative intensity) for the molecular ion $[\mathrm{M}]$ and reporting the molecular ion $[\mathrm{M}+\mathrm{H}]$ or $[\mathrm{M}+\mathrm{Na}]$. The purification of the compounds was performed by recrystallization in ethanol and confirmed by determining the melting range on an MQAPF-302 hotplate (Microquímica).

\section{Preparation of isosafrole (2)}

To a $125 \mathrm{~mL}$ flask equipped with reflux condenser and

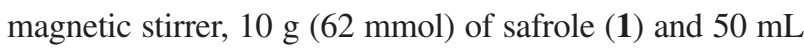
$(150 \mathrm{mmol})$ of $3.0 \mathrm{M} \mathrm{KOH}$ in $n$-butanol were added. The reaction mixture was stirred under reflux for $6 \mathrm{~h}$. Afterwards, the mixture was neutralized with $10 \% \mathrm{HCl}$ and the organic phase was washed successively with distilled water and aqueous $\mathrm{NaCl}$ solution. The $n$-butanol was evaporated and the residue was distilled to obtain isosafrole (2) as a colorless liquid. Yield 90\%; ${ }^{1} \mathrm{H}$ NMR $\left(400 \mathrm{MHz}\right.$, DMSO- $\left.d_{6}\right)$ $\delta$ 6.75-6.91 (m, 5H), $5.81(\mathrm{~s}, 2 \mathrm{H}), 1.83(\mathrm{~d}, 3 \mathrm{H}) ;{ }^{13} \mathrm{C} \mathrm{NMR}$ $\left(101 \mathrm{MHz}, \mathrm{DMSO}-d_{6}\right) \delta 148.13$ (C-7), 146.87 (C-6), 132.21 (C-4), 130.46 (C-3), 123.32 (C-2), 120.22 (C-9), 108.11 (C-8), 105.47 (C-5), 100.88 (C-10), 18.09 (C-1).

Preparation of 11,12-methylenedioxy-6-methyl-3,4,6,7-tetrahydronaphtalene-2,5-dicarboxylic anhydride (3) ${ }^{16}$

A mixture containing isosafrole (2) $(80 \mathrm{mmol})$, maleic anhydride $(101 \mathrm{mmol})$ and $40 \mathrm{~mL} o$-xylene was refluxed for about $4 \mathrm{~h}$ at the boiling point of the solvent. After reflux, the reaction mixture was cooled and produced a precipitate, and the solid obtained was washed with ethanol and extracted with hot chloroform to give pale yellow crystals. Yield 52\%; mp $141{ }^{\circ} \mathrm{C}\left(142-143{ }^{\circ} \mathrm{C}\right) ;{ }^{17} \mathrm{IR}(\mathrm{KBr})$ $\mathrm{v} / \mathrm{cm}^{-1}$ 2977, 2933, $2900(\mathrm{C}-\mathrm{H}), 1789,1724(\mathrm{C}=\mathrm{O})$, 1497, $1479(\mathrm{C}=\mathrm{C}), 1385\left(\mathrm{CH}_{3}\right), 1234,1031(\mathrm{C}-\mathrm{O}), 908$, 863, $754\left(\mathrm{CH}_{\mathrm{Ar}}\right) ;{ }^{1} \mathrm{H}$ NMR (400 MHz, DMSO- $\left.d_{6}\right) \delta 6.86$ (s, 1H, H-10), 6.54 (s, 1H, H-13), 5.87 (s, 2H, H-14), 3.90 (d, J $6.2 \mathrm{~Hz}, 1 \mathrm{H}, \mathrm{H}-4), 3.03$ (dd, J 6.2, $3.7 \mathrm{~Hz}, 1 \mathrm{H}, \mathrm{H}-3$ ), 2.54 and $2.46(\mathrm{~m}, 2 \mathrm{H}, \mathrm{H}-7 \mathrm{a}$ and $7 \mathrm{~b}), 2.15-2.09(\mathrm{~m}, 1 \mathrm{H}$, H-6), 1.02 (d, J 6.9 Hz, 3H, H-15); ${ }^{13} \mathrm{C}$ NMR (101 MHz, DMSO- $\left.d_{6}\right) \delta 173.61$ (C-2), 173.53 (C-5), 145.59 (C-11), 145.05 (C-12), 129.92 (C-8), 125.11 (C-9), 109.58 (C-10), 108.10 (C-13), 100.67 (C-14), 46.68 (C-3), 46.10 (C-4), 34.96 (C-7), 29.75 (C-6), 19.05 (C-15).

General procedure for the preparation of the cyclic imides $(4 a-4 j)$

In a $10 \mathrm{~mL}$ flask, a mixture of substituted aromatic 
aniline and the anhydride in $5 \mathrm{~mL}$ of acetic acid was refluxed for $3 \mathrm{~h}$. After completion, the reaction mixture was cooled to room temperature and a precipitate formed, which was filtered, washed with water and dried. The precipitate was purified by recrystallization from ethanol.

1-Phenyl-7,8-(11,12-methylenedioxyphenyl)-6-methyl3,4,6,7-tetrahydronaphtalene-2,5-dicarboxyimide (4a)

Yield 62\%; pale yellow crystals; mp $246-248{ }^{\circ} \mathrm{C}$ (literature: $\left.249{ }^{\circ} \mathrm{C}\right) ;{ }^{18} \mathrm{IR}(\mathrm{KBr}) \mathrm{v} / \mathrm{cm}^{-1} 3090\left(\mathrm{C}-\mathrm{H}_{\mathrm{Ar}}\right), 2925$, 2986, $2844\left(\mathrm{C}-\mathrm{H}_{\mathrm{Ali}}\right), 1678(\mathrm{C}=\mathrm{O}), 1589,1571\left(\mathrm{C}=\mathrm{C}_{\mathrm{Ar}}\right)$, $1421\left(\mathrm{CH}_{3}\right), 1319,1089(\mathrm{C}-\mathrm{O})$; ${ }^{1} \mathrm{H}$ NMR $(400 \mathrm{MHz}$, DMSO- $\left.d_{6}\right) \delta 7.49(\mathrm{~m}, 2 \mathrm{H}, \mathrm{H}-18$ and 20$), 7.42(\mathrm{~m}, 1 \mathrm{H}$, $\mathrm{H}-19), 7.23$ (m, 2H, H-17 and 21), 7.11 (s, 1H, H-10), 6.76 (s, 1H, H-13), 5.99 (dd, J 13.1, 1.0 Hz, 2H, H-14a and H-14b), 4.26 (d, $J 8.9 \mathrm{~Hz}, 1 \mathrm{H}, \mathrm{H}-4), 3.50$ (dd, $J$ 8.9, $5.4 \mathrm{~Hz}, 1 \mathrm{H}, \mathrm{H}-3$ ), 2.74 and 2.46 (m, 2H, H-7a and 7b), 2.30 (m, $J$ 10.7, 7.6, 3.7 Hz, 1H, H-6), 1.08 (d, J 7.0 Hz, 3H, $\mathrm{H}-15) ;{ }^{13} \mathrm{C}$ NMR (101 MHz, DMSO- $\left.d_{6}\right) \delta 177.05$ (C-2), 176.40 (C-5), 146.28 (C-11), 145.70 (C-12), 132.33 (C-16), 129.74 (C-8), 128.97 (C-18 and 20), 128.41 (C-19), 127.06 (C-17 and 21), 122.37 (C-9), 109.35 (C-10), 108.73 (C-13), 100.84 (C-14), 43.77 (C-3), 42.99 (C-4), 34.68 (C-7), 29.68 (C-6), 16.27 (C-15).

1-(19-Methylphenyl)-7,8-(11,12-methylenedioxyphenyl)6-methyl-3,4,6,7-tetrahydronaphtalene-2,5-dicarboxyimide (4b)

Yield 58\%; pale yellow crystals; mp $261-263{ }^{\circ} \mathrm{C}$; IR $(\mathrm{KBr}) \mathrm{v} / \mathrm{cm}^{-1} 3053\left(\mathrm{C}-\mathrm{H}_{\mathrm{Ar}}\right), 2964,2931\left(\mathrm{C}-\mathrm{H}_{\mathrm{Ali}}\right), 1706$ $(\mathrm{C}=\mathrm{O}), 1516,1502,1483\left(\mathrm{C}=\mathrm{C}_{\mathrm{Ar}}\right), 1386\left(\mathrm{CH}_{3}\right) ; 1170$, $1039(\mathrm{C}-\mathrm{O}) ;{ }^{1} \mathrm{H}$ NMR $\left(400 \mathrm{MHz}, \mathrm{DMSO}-d_{6}\right) \delta 7.27$ (d, $J 8.0 \mathrm{~Hz}, 2 \mathrm{H}, \mathrm{H}-17$ and $\mathrm{H}-21$ ), 7.10-7.07 (m, 3H, H-18, $\mathrm{H}-20$ and $\mathrm{H}-10), 6.75$ (s, 1H, H-13), 5.98 (dd, $J$ 13.2, $1.0 \mathrm{~Hz}, 2 \mathrm{H}, \mathrm{H}-14 \mathrm{a}$ and H-14b), 4.23 (d, J $8.9 \mathrm{~Hz}, 1 \mathrm{H}$, $\mathrm{H}-4$ ), 3.47 (dd, $J$ 8.9, $5.5 \mathrm{~Hz}, 1 \mathrm{H}, \mathrm{H}-3$ ), 2.73 and 2.43 (m, $2 \mathrm{H}, \mathrm{H}-7 \mathrm{a}$ and $\mathrm{H}-7 \mathrm{~b}), 2.33$ (s, 3H, $\left.\mathrm{CH}_{3}\right), 2.31-2.24(\mathrm{~m}, 1 \mathrm{H}$, H-6), 1.06 (d, J 7.0 Hz, 3H, H-15); ${ }^{13} \mathrm{C}$ NMR (101 MHz, DMSO- $\left.d_{6}\right) \delta 177.60(\mathrm{C}-2), 176.95(\mathrm{C}-5), 146.71(\mathrm{C}-11)$, 146.14 (C-12), 138.40 (C-19), 130.18 (C-16), 129.90 (C-18 and C-20), 127.31 (C-17 and 21), 122.88 (C-9), 109.83 (C-10), 109.19 (C-13), 101.30 (C-14), 44.19 (C-3), 43.40 (C-4), 35.14 (C-7), 30.13 (C-6), $21.19\left(\mathrm{CH}_{3}\right), 16.74(\mathrm{C}-15)$; HRMS $\mathrm{m} / z$, calcd. for $\mathrm{C}_{21} \mathrm{H}_{19} \mathrm{NO}_{4}[\mathrm{M}+\mathrm{Na}]^{+}: 372.1211$, found: 372.1191 .

1-(19-Ethylphenyl)-7,8-(11,12-methylenedioxyphenyl)6-methyl-3,4,6,7-tetrahydronaphtalene-2,5-dicarboxyimide (4c)

Yield 61\%; pale yellow crystals; mp 256-258 ${ }^{\circ} \mathrm{C}$; IR $(\mathrm{KBr}) \vee / \mathrm{cm}^{-1} 3047\left(\mathrm{C}-\mathrm{H}_{\mathrm{Ar}}\right), 2970,2929,2891\left(\mathrm{C}-\mathrm{H}_{\mathrm{Ali}}\right)$,
$1703(\mathrm{C}=\mathrm{O}), 1517,1500,1483\left(\mathrm{C}=\mathrm{C}_{\mathrm{Ar}}\right), 1384\left(\mathrm{CH}_{3}\right), 1166$, $1039(\mathrm{C}-\mathrm{O}) ;{ }^{1} \mathrm{H}$ NMR $\left(400 \mathrm{MHz}, \mathrm{DMSO}-d_{6}\right) \delta 7.31(\mathrm{~d}$, $J 8.5 \mathrm{~Hz}, 2 \mathrm{H}, \mathrm{H}-18$ and $\mathrm{H}-20), 7.13-7.07$ (m, 3H, H-17, H-21 and H-10), 6.75 (s, 1H, H-13), 5.98 (dd, $J$ 12.8, $1.0 \mathrm{~Hz}, 2 \mathrm{H}, \mathrm{H}-14 \mathrm{a}$ and H-14b ), 4.23 (d, J $8.9 \mathrm{~Hz}, 1 \mathrm{H}, \mathrm{H}-4$ ), 3.47 (dd, $J 8.9,5.5 \mathrm{~Hz}, 1 \mathrm{H}, \mathrm{H}-3), 2.73$ and $2.44(\mathrm{~m}, 2 \mathrm{H}$, $\mathrm{H}-7 \mathrm{a}$ and $\mathrm{H}-7 \mathrm{~b}$ ), 2.63 (q, $J 7.6 \mathrm{~Hz}, 2 \mathrm{H}, \mathrm{CH}_{2}$ ), 2.34-2.24 (m, $1 \mathrm{H}, \mathrm{H}-6), 1.19$ (t, $\left.J 7.6 \mathrm{~Hz}, 3 \mathrm{H}, \mathrm{CH}_{3}\right), 1.06(\mathrm{~d}, J 7.0 \mathrm{~Hz}, 3 \mathrm{H}$, $\mathrm{H}-15) ;{ }^{13} \mathrm{C}$ NMR (101 MHz, DMSO- $\left.d_{6}\right) \delta 177.17$ (C-2), 176.52 (C-5), 146.26 (C-11), 145.62 (C-12), 144.15 (C19), 129.36 (C-16), 129.72 (C-8), 128.30 (C-18 and C-20), 126.93 (C-17 and 21), 122.14 (C-9), 109.38 (C-10), 108.74 (C-13), 100.85 (C-14), 43.74 (C-3), 42.93 (C-4), 34.70 (C7), 29.68 (C-6), $27.84\left(\mathrm{CH}_{2}\right), 16.27(\mathrm{C}-15), 15.53\left(\mathrm{CH}_{3}\right)$; HRMS $m / z$, calcd. for $\mathrm{C}_{22} \mathrm{H}_{21} \mathrm{NO}_{4}[\mathrm{M}+\mathrm{Na}]^{+}: 386.1368$, found: 386.1361 .

1-(19-Isopropylphenyl)-7,8-(11,12-methylenedioxyphenyl)6-methyl-3,4,6,7-tetrahydronaphtalene-2,5-dicarboxyimide (4d)

Yield 58\%; pale yellow crystals; mp 187-189 ${ }^{\circ} \mathrm{C}$; IR $(\mathrm{KBr}) \vee / \mathrm{cm}^{-1} 3075\left(\mathrm{C}-\mathrm{H}_{\mathrm{Ar}}\right), 2967,2925,2881\left(\mathrm{C}-\mathrm{H}_{\mathrm{Ali}}\right)$, $1705(\mathrm{C}=\mathrm{O}), 1507,1485\left(\mathrm{C}=\mathrm{C}_{\mathrm{Ar}}\right), 1388\left(\mathrm{CH}_{3}\right), 1166,1039$ $(\mathrm{C}-\mathrm{O}) ;{ }^{1} \mathrm{H}$ NMR (400 MHz, DMSO- $\left.d_{6}\right) \delta 7.34(\mathrm{~d}, J 8.2 \mathrm{~Hz}$, 2H, H-18 and 20), 7.12 (d, J 8.5 Hz, 2H, H-17 and H-21), 7.09 (s, 1H, H-10), 6.75 (s, 1H, H-13), 5.98 (dd, $J$ 12.4, $1.0 \mathrm{~Hz}, 2 \mathrm{H}, \mathrm{H}-14 \mathrm{a}$ and 14b), 4.24 (d, J $8.9 \mathrm{~Hz}, 1 \mathrm{H}, \mathrm{H}-4)$, 3.47 (dd, J 9.0, 5.6 Hz, 1H, H-3), 2.92 (m, 1H, CH), 2.73 and $2.44(\mathrm{~m}, 2 \mathrm{H}, \mathrm{H}-7 \mathrm{a}$ and $7 \mathrm{~b}), 2.29(\mathrm{~m}, 1 \mathrm{H}, \mathrm{H}-6), 1.21$ (d, J $6.9 \mathrm{~Hz}, 6 \mathrm{H}, \mathrm{CH}_{3}$ ) and $1.06(\mathrm{~d}, J 7.0 \mathrm{~Hz}, 3 \mathrm{H}, \mathrm{H}-15)$; ${ }^{13} \mathrm{C}$ NMR (101 MHz, DMSO- $\left.d_{6}\right) \delta 177.16(\mathrm{C}-2), 176.50$ (C-5), 148.68 (C-9), 146.26 (C-11), 145.68 (C-12), 129.99 (C-16), 129.69 (C-8), 126.91 (C-17 and C-21), 126.83 (C-18 and C-20), 122.41 (C-9), 109.36 (C-10), 108.72 (C-13), 100.83 (C-14), 43.73 (C-3), 42.90 (C-4), 34.70 (C-7), 33.18 (C-6), $29.66(\mathrm{CH}), 23.77(\mathrm{CH} 3)$ and 16.22 (C-15); HRMS $m / z$, calcd. for $\mathrm{C}_{23} \mathrm{H}_{23} \mathrm{NO}_{4}[\mathrm{M}+\mathrm{Na}]^{+}$: 400.1524, found: 400.1504 .

1-(19-Methoxyphenyl)-7,8-(11,12-methylenedioxyphenyl)6-methyl-3,4,6,7-tetrahydronaphtalene-2,5-dicarboxyimide (4e)

Yield 59\%; pale yellow crystals; mp 249-251 ${ }^{\circ} \mathrm{C}$; IR $(\mathrm{KBr}) \mathrm{v} / \mathrm{cm}^{-1}$ 3059, $3014\left(\mathrm{C}-\mathrm{H}_{\mathrm{Ar}}\right), 2962,2931,2900$ $\left(\mathrm{C}-\mathrm{H}_{\mathrm{Ali}}\right), 1703(\mathrm{C}=\mathrm{O}), 1517,1485\left(\mathrm{C}=\mathrm{C}_{\mathrm{Ar}}\right), 1390\left(\mathrm{CH}_{3}\right)$, 1166, $1035(\mathrm{C}-\mathrm{O}) ;{ }^{1} \mathrm{H}$ NMR (400 MHz, DMSO- $\left.d_{6}\right) \delta 7.12$ (d, J $9.0 \mathrm{~Hz}, 2 \mathrm{H}, \mathrm{H}-17$ and $\mathrm{H}-21), 7.09$ (s, $1 \mathrm{H}, \mathrm{H}-10), 7.01$ (d, $J 9.0 \mathrm{~Hz}, 2 \mathrm{H}, \mathrm{H}-18$ and $\mathrm{H}-20), 5.98(\mathrm{dd}, J 13.2,0.8 \mathrm{~Hz}$, $2 \mathrm{H}, \mathrm{H}-14 \mathrm{a}$ and $\mathrm{H}-14 \mathrm{~b}), 4.22$ (d, $J 8.8 \mathrm{~Hz}, 1 \mathrm{H}, \mathrm{H}-4), 3.78$ (s, $\left.3 \mathrm{H}, \mathrm{OCH}_{3}\right), 3.46$ (dd, $\left.J 8.8,5.6 \mathrm{~Hz}, 1 \mathrm{H}, \mathrm{H}-3\right), 2.72$ and 2.43 (m, 2H, H-7a and H-7b), 2.27 (m, 1H, H6), 1.06 (d, 
$J 7.0 \mathrm{~Hz}, 3 \mathrm{H}, \mathrm{H}-15) ;{ }^{13} \mathrm{C}$ NMR (101 MHz, DMSO- $\left.d_{6}\right)$ $\delta 177.22$ (C-2), 176.58 (C-5), 158.97 (C-19), 146.25 (C-11), 145.69 (C-12), 129.72 (C-16), 128.29 (C-17 and C-21), 124.83 (C-9), 122.50 (C-16), 114.10 (C-18 and C-20), 109.39 (C-10), 108.73 (C-13), 100.84 (C-14), 55.43 $\left(\mathrm{OCH}_{3}\right), 43.70(\mathrm{C}-3), 42.91(\mathrm{C}-4), 34.70(\mathrm{C}-7), 29.70(\mathrm{CH})$, 16.25 (C-15); HRMS $m / z$, calcd. for $\mathrm{C}_{21} \mathrm{H}_{19} \mathrm{NO}_{5}[\mathrm{M}+\mathrm{Na}]^{+}$: 388.1160, found: 388.1140 .

1-(19-Nitrophenyl)-7,8-(11,12-methylenedioxyphenyl)6-methyl-3,4,6,7-tetrahydronaphtalene-2,5-dicarboxyimide (4f)

Yield 63\%; yellow crystals; mp 222-224 ${ }^{\circ} \mathrm{C}$; IR $(\mathrm{KBr})$ $\mathrm{V} / \mathrm{cm}^{-1} 3081\left(\mathrm{C}-\mathrm{H}_{\mathrm{Ar}}\right), 2962,2920,2877\left(\mathrm{C}-\mathrm{H}_{\mathrm{Ali}}\right), 1707$ $(\mathrm{C}=\mathrm{O}), 1523,1342\left(\mathrm{NO}_{2}\right), 1498,1481\left(\mathrm{C}=\mathrm{C}_{\mathrm{Ar}}\right), 1382\left(\mathrm{CH}_{3}\right)$, 1166, $1036(\mathrm{C}-\mathrm{O}) ;{ }^{1} \mathrm{H}$ NMR (400 MHz, DMSO- $\left.d_{6}\right) \delta 8.34$ (d, J $9.2 \mathrm{~Hz}, 2 \mathrm{H}, \mathrm{H}-18$ and H-20), 7.59 (d, J $9.2 \mathrm{~Hz}, 2 \mathrm{H}$, $\mathrm{H}-17$ and H-21), 7.09 (s, 1H, H-10), 6.74 (s, 1H, H-13), 5.98 (dd, $J$ 14.0, $0.9 \mathrm{~Hz}, 2 \mathrm{H}, \mathrm{H}-14 \mathrm{a}$ and 14b), 4.29 (d, $J 9.0 \mathrm{~Hz}, 1 \mathrm{H}, \mathrm{H}-4), 3.54$ (dd, J 9.0, $5.5 \mathrm{~Hz}, 1 \mathrm{H}, \mathrm{H}-3$ ), 2.72 and $2.45(\mathrm{~m}, 2 \mathrm{H}, \mathrm{H}-7 \mathrm{a}$ and $7 \mathrm{~b}), 2.28(\mathrm{~m}, 1 \mathrm{H}, \mathrm{H}-6), 1.10$ (d, $J$ 7.0 Hz, 3H, H-15); ${ }^{13} \mathrm{C}$ NMR (101 MHz, DMSO- $d_{6}$ ) $\delta 176.51$ (C-2), 175.91 (C-5), 146.66 (C-19), 146.38 (C11), 145.76 (C-12), 137.83 (C-16), 129.94 (C-8), 128.00 (C-17 and C-21), 124.24 (C-18 and C-20), 122.07 (C-9), 109.32 (C-10), 108.72 (C-13), 100.88 (C-14a, 14b), 43.95 (C-3), 43.32 (C-4), 34.59 (C-7a, 7b), 29.77 (C-6) and $16.41(\mathrm{C}-15)$.

1-(19-Bromophenyl)-7,8-(11,12-methylenedioxyphenyl)6-methyl-3,4,6,7-tetrahydronaphtalene-2,5-dicarboxyimide (4g)

Yield 56\%; pale yellow crystals; mp $259-261^{\circ} \mathrm{C}$; IR $(\mathrm{KBr}) v / \mathrm{cm}^{-1}$ 3093, $3070\left(\mathrm{C}-\mathrm{H}_{\mathrm{Ar}}\right), 2964,2927,2891$ $\left(\mathrm{C}-\mathrm{H}_{\mathrm{Ali}}\right), 1707(\mathrm{C}=\mathrm{O}), 1481\left(\mathrm{C}=\mathrm{C}_{\mathrm{Ar}}\right), 1384\left(\mathrm{CH}_{3}\right), 1166$, $1039(\mathrm{C}-\mathrm{O}) ;{ }^{1} \mathrm{H}$ NMR $\left(400 \mathrm{MHz}, \mathrm{DMSO}-d_{6}\right) \delta 7.68(\mathrm{~d}$, $J 8.5 \mathrm{~Hz}, 2 \mathrm{H}, \mathrm{H}-17$ and H-21), 7.21 (d, $J 8.5 \mathrm{~Hz}, 2 \mathrm{H}, \mathrm{H}-18$ and $\mathrm{H}-20), 7.08$ (s, 1H, H-10), 6.74 (s, 1H, H-13), 5.98 (d, $J 14.0 \mathrm{~Hz}, 2 \mathrm{H}, \mathrm{H}-14), 4.24$ (d, J $8.8 \mathrm{~Hz}, 1 \mathrm{H}, \mathrm{H}-4), 3.48$ (dd, $J$ 8.5, $5.7 \mathrm{~Hz}, 1 \mathrm{H}, \mathrm{H}-3), 2.72$ and $2.44(\mathrm{~m}, 2 \mathrm{H}, \mathrm{H}-7 \mathrm{a}$ and H-7b), 2.32-2.22 (m, 1H, H-6), 1.07 (d, J 6.9 Hz, 3H, $\mathrm{H}-15) ;{ }^{13} \mathrm{C}$ NMR (101 MHz, DMSO- $\left.d_{6}\right) \delta 176.81$ (C-2), 176.18 (C-5), 146.31 (C-11), 145.73 (C-12), 132.20 (C-18 and C-20), 131.57 (C-16), 129.85 (C-8), 129.17 (C-17 and C-21), 122.26 (C-9), 121.39 (C-19), 109.35 (C-10), 108.74 (C-13), 100.87 (C-14a, 14b), 43.83 (C-3), 43.13 (C-4), 34.64 (C-7a, 7b), 29.68 (C-6) and 16.37 (C-15); HRMS $m / z$, calcd. for $\mathrm{C}_{20} \mathrm{H}_{16} \mathrm{BrNO}_{4}[\mathrm{M}+\mathrm{H}]$ : 414.0341, found: 414.0254 or $\mathrm{C}_{20} \mathrm{H}_{16} \mathrm{BrNO}_{4}[\mathrm{M}+\mathrm{H}]$ : 416.0320, found: 416.0235 .
1-(19-Chlorophenyl)-7,8-(11,12-methylenedioxyphenyl)6-methyl-3,4,6,7-tetrahydronaphtalene-2,5-dicarboxyimide (4h)

Yield 59\%; pale yellow crystals; mp $247-249{ }^{\circ} \mathrm{C}$; IR $(\mathrm{KBr}) \mathrm{v} / \mathrm{cm}^{-1} 3081\left(\mathrm{C}-\mathrm{H}_{\mathrm{Ar}}\right), 2962,2920,2877\left(\mathrm{C}-\mathrm{H}_{\mathrm{Ali}}\right)$, $1707(\mathrm{C}=\mathrm{O}), 1502,1483\left(\mathrm{C}=\mathrm{C}_{\mathrm{Ar}}\right), 1390\left(\mathrm{CH}_{3}\right), 1166$, $1035(\mathrm{C}-\mathrm{O}) ;{ }^{1} \mathrm{H}$ NMR $\left(400 \mathrm{MHz}, \mathrm{DMSO}-d_{6}\right) \delta 8.34(\mathrm{~d}$, $J 9.2 \mathrm{~Hz}, 2 \mathrm{H}, \mathrm{H}-18$ and H-20), 7.59 (d, J $9.2 \mathrm{~Hz}, 2 \mathrm{H}$, $\mathrm{H}-17$ and H-21), 7.09 (s, 1H, H-10), 6.74 (s, 1H, H-13), 5.98 (dd, J 14.0, 0.9 Hz, 2H, H-14), 4.29 (d, J $9.0 \mathrm{~Hz}, 1 \mathrm{H}$, $\mathrm{H}-4), 3.54$ (dd, $J 9.0,5.5 \mathrm{~Hz}, 1 \mathrm{H}, \mathrm{H}-3$ ), 2.72 and 2.45 (m, 2H, H-7a and 7b), 2.28 (m, 1H, H-6), 1.10 (d, J 7.0 Hz, $3 \mathrm{H}, \mathrm{H}-15) ;{ }^{13} \mathrm{C}$ NMR (101 MHz, DMSO- $\left.d_{6}\right) \delta 176.51$ (C-2), 175.91 (C-5), 146.66 (C-19), 146.38 (C-11), 145.76 (C-12), 137.83 (C-16), 129.94 (C-8), 128.00 (C-17 and C-21), 124.24 (C-18 and C-20), 122.07 (C-9), 109.32 (C-10), 108.72 (C-13), 100.88 (C-14a, 14b), 43.95 (C-3), 43.32 (C-4), 34.59 (C-7a, 7b), 29.77 (C-6) and 16.41 (C-15); HRMS $m / z$, calcd. for $\mathrm{C}_{20} \mathrm{H}_{16} \mathrm{ClNO}_{4}[\mathrm{M}+\mathrm{H}]$ : 370.0846, found: 370.0858 .

Acid-1-(16-acetic)-7,8-(11,12-methylenedioxyphenyl)6-methyl-3,4,6,7-tetrahydronaphtalene-2,5-dicarboxyimide (4i)

Yield 58\%; yellow crystals; mp $177-179^{\circ} \mathrm{C}$; IR (KBr) $\mathrm{v} / \mathrm{cm}^{-1}$ 2504-2906 (OH), $3082\left(\mathrm{C}-\mathrm{H}_{\mathrm{Ar}}\right), 2968,2943,2906$ $\left(\mathrm{C}-\mathrm{H}_{\mathrm{Ali}}\right), 1730,1701(\mathrm{C}=\mathrm{O}), 1504,1485\left(\mathrm{C}=\mathrm{C}_{\mathrm{Ar}}\right), 1392$ $\left(\mathrm{CH}_{3}\right), 1166,1035(\mathrm{C}-\mathrm{O}) ;{ }^{1} \mathrm{H}$ NMR (400 MHz, DMSO- $\left.d_{6}\right)$ $\delta 6.46$ (s, 1H, H-10), 5.98 (s, 1H, H-13), 5.34 (dd, J 9.6, $1.2 \mathrm{~Hz}, 2 \mathrm{H}, \mathrm{H}-14), 3.52$ (d, J $\left.1.8 \mathrm{~Hz}, 2 \mathrm{H}, \mathrm{CH}_{2}\right), 3.47$ (d, $J 8.9 \mathrm{~Hz}, 1 \mathrm{H}, \mathrm{H}-4), 2.73$ and 1.93 (m, 2H, H-7a and 7b), 1.93 (m, 1H, H-3), 1.62 (m, 1H, H-6), 0.61 (d, J 7.0 Hz, $3 \mathrm{H}, \mathrm{H}-15) ;{ }^{13} \mathrm{C}$ NMR (101 MHz, DMSO- $\left.d_{6}\right) \delta 175.73(\mathrm{C}-2)$, 175.10 (C-5), 166.96 (C=O), 145.44 (C-11), 144.94 (C-12) 129.34 (C-8), 121.07 (C-9), 108.27 (C-10), 107.38 (C-13), 99.68 (C-14), 42.96 (C-3), 42.81 (C-4), $38.71\left(\mathrm{CH}_{2}\right), 33.75$ (C-7), 29.36 (C-6) and 15.81 (C-15); HRMS $m / z$, calcd. for $\mathrm{C}_{16} \mathrm{H}_{15} \mathrm{NO}_{6}[\mathrm{M}+\mathrm{H}]:$ 318.0978, found: 318.0959 .

1-(18-Nitro-19-fluorophenyl)-7,8-(11,12-methylenedioxyphenyl)-6-methyl-3,4,6,7-tetrahydronaphtalene2,5-dicarboxyimide $(4 \mathbf{j})^{17}$

Yield 60\%; pale yellow crystals; mp: $180-183{ }^{\circ} \mathrm{C}$; IR $(\mathrm{KBr}) \mathrm{v} / \mathrm{cm}^{-1} 3082\left(\mathrm{C}-\mathrm{H}_{\mathrm{Ar}}\right), 2962,2920,2877\left(\mathrm{C}-\mathrm{H}_{\mathrm{Ali}}\right)$, $1707(\mathrm{C}=\mathrm{O}), 1502,1483\left(\mathrm{C}=\mathrm{C}_{\mathrm{Ar}}\right) ;{ }^{1} \mathrm{H}$ NMR $(500 \mathrm{MHz}$, DMSO- $\left.d_{6}\right) \delta 8.17$ (dd, $\left.J 6.8,2.5 \mathrm{~Hz}, 1 \mathrm{H}, \mathrm{H}-17\right), 7.79-7.68$ (m, 2H, H-20 and H-21), 7.08 (s, 1H, H-10), 6.74 (s, 1H, H-13), 5.97 (dd, J 17.8, 1.0 Hz, 2H, H-14), 4.27 (d, $J 9.0 \mathrm{~Hz}, 1 \mathrm{H}, \mathrm{H}-4), 3.52$ (dd, J 9.2, $5.9 \mathrm{~Hz}, 1 \mathrm{H}, \mathrm{H}-3$ ), 2.70 and 2.46 (m, 2H, H-7a and H-7b), 2.25 (ddd, $J$ 12.6, 9.1, $3.6 \mathrm{~Hz}, 1 \mathrm{H}, \mathrm{H}-6), 1.13$ (d, J 7.0 Hz, 3H, H-15); ${ }^{13} \mathrm{C}$ NMR 
$\left(126 \mathrm{MHz}, \mathrm{DMSO}-d_{6}\right) \delta 176.49(\mathrm{C}-2), 175.90(\mathrm{C}-5), 153.92$ (d, J 263.5 Hz, C-19), 146.30 (C-11), 145.70 (C-12), 136.74

(d, J $8.5 \mathrm{~Hz}, \mathrm{C}-16), 135.00$ (d, $J 9.5 \mathrm{~Hz}, \mathrm{C}-21), 130.20$ (C-8), 128.61 (d, J 3.6 Hz, C-18), 124.66 (C-17), 122.09 (C-9), 119.12 (d, J 22.1 Hz, C-20), 109.28 (C-10), 108.61 (C-13), 100.81 (C-14), 43.88 (C-3), 43.44 (C-4), 34.54 (C-7), 29.87 (C-6), 16.54 (C-15); HRMS $\mathrm{m} / \mathrm{z}$, calcd. for $\mathrm{C}_{20} \mathrm{H}_{15} \mathrm{FN}_{2} \mathrm{O}_{6}[\mathrm{M}+\mathrm{Na}]$ : 421.0914 , found: 421.0792 .

\section{Antifungal activity}

\section{Test substance}

The emulsions of the synthesized compounds were prepared, aiming to improve the solubilization of the substances for use in the tests. For this, 5\% DMSO and 2\% Tween 80 (Sigma-Aldrich, São Paulo, Brazil) were used, completing the volume with sterile distilled water. These emulsions were used to make the dilutions used in the tests. ${ }^{35,36}$

\section{Culture media}

Sabouraud dextrose agar (SDA) (Difco Laboratories Ltd., Detroit, USA) was used for maintenance of the fungal strains. For biological activity assays, Roswell Park Memorial Institute Medium (RPMI)-1640 medium with L-glutamine and no sodium bicarbonate (Difco Laboratories Ltd., Detroit, USA and INLAB, São Paulo, Brazil) was used. Culture media were prepared according to the manufacturer's instructions and sterilized by autoclaving at $121^{\circ} \mathrm{C}, 1 \mathrm{~atm}$ for $15 \mathrm{~min}$.

\section{Microorganisms}

For the biological activity assays of the test products, the following strains were used: Cryptococcus gattii INCQS-40113, Cryptococcus neoformans LM-260, Cryptococcus neoformans FCF-119, Candida parapsilosis ATCC-22019, Candida krusei LM-656 and Candida albicans ATCC-76645. The microorganisms belong to MICOTECA of the Mycology Laboratory, Department of Pharmaceutical Sciences (DCF), Health Sciences Center (CCS) of the Federal University of Paraíba (UFPB). The strains were maintained in SDA at $4{ }^{\circ} \mathrm{C}$. For use in the assays, the fungi were harvested in SDA with incubation at $35 \pm 2{ }^{\circ} \mathrm{C}$ for 24-48 h. The microorganism suspension was prepared at 0.5 on the McFarland scale and was adjusted by the use of a spectrophotometer (Leitz-Photometer 340-800) to $90 \%$ transmittance $(\mathrm{T})(530 \mathrm{~nm})$, corresponding to approximately $10^{6}$ colony-forming unit (CFU) $\mathrm{mL}^{-1} \cdot{ }^{37-39}$

Determination of minimum inhibitory concentration (MIC)

The determination of the MIC of the substances in fungal strains was carried out by means of the microdilution technique in liquid medium in a U-bottom 96-well microplate (TPP, Trasadingen, Switzerland, Europa). Initially, $100 \mu \mathrm{L}$ of double concentrated RPMI medium was distributed to the wells of the microdilution plates. Subsequently, $100 \mu \mathrm{L}$ of the substances were dispensed into the wells of the first row of the plate. Finally, $10 \mu \mathrm{L}$ of the suspensions of the fungal strains were added to the wells, where each plate column specifically referred to one species. At the same time, controls were carried out to prove the viability of the strains (RPMI + yeast) and sterility of the culture medium (RPMI). A negative control with amphotericin B $\left(0.034 \mu \mathrm{mol} \mathrm{mL}^{-1}\right)$ was also performed for inhibition of fungi. The prepared plates were aseptically closed and incubated at a temperature of $35 \pm 2{ }^{\circ} \mathrm{C}$ for $24-48 \mathrm{~h}$. The MIC for each product was defined as the lowest concentration capable of visually inhibiting microbial growth.

\section{Supplementary Information}

Supplementary information is available free of charge at http://jbcs.sbq.org.br as PDF file.

\section{Acknowledgments}

The authors gratefully acknowledge the financial support from the Brazilian agencies: Conselho Nacional de Desenvolvimento Científico e Tecnológico (CNPq), Coordenação de Aperfeiçoamento de Pessoal de Nível Superior-Brazil (CAPES), Programa de Apoio a Núcleos de Excelência (PRONEX-FACEPE) and Financiadora de Estudos e Projetos (FINEP). The authors thank Laboratório Multiusuário de Caracterização e Análise-LMCA at Universidade Federal da Paraíba (UFPB) for carrying out the NMR spectra of hydrogen and carbon and for the high resolution mass spectrum. The authors also acknowledge the physical structure and computational support provided by Universidade Federal da Paraíba (UFPB), the computer resources of Centro Nacional de Processamento de Alto Desempenho em São Paulo (CENAPAD-SP) and Chemistry Institute of Campinas State University (UNICAMP) and Dr A. Leyva (USA) that helped with English translation and editing of the manuscript. This study was in part financed by the Coordenação de Aperfeiçoamento de Pessoal de Nível Superior-Brazil (CAPES) through the research project Bioinformática Estrutural de Proteínas: Modelos, Algoritmos e Aplicações Biotecnológicas (Edital Biologia Computacional 51/2013, process AUXPE1375/2014CAPES). G.B.R. acknowledges support from the Brazilian National Council for Scientific and Technological Development (CNPq grant No. 309761/2017-4). 


\section{Author Contributions}

P.F.A., R.F.V., B.F.L. conceived and designed the experiment; R.F.V., H.D.S.S., K.M.S.A, N.A.S.C. performed the experiments; H.D.S.S., R.F.V., N.A.S.C., in silico study and analyzed the data; L.V.C., E.O.L. performed the antifungal study; L.E.G.C., G.B.R. computational study; R.F.V, P.F.A-F., G.B.R., J.M.B-F., wrote the paper.

\section{References}

1. Sidrim, J. J. C.; Rocha, M. F. G.; Micologia Médica à Luz de Autores Contemporâneos, $1^{\text {st }}$ ed.; Guanabara Koogan: Rio de Janeiro, Brazil, 2003.

2. Levidiotou-Stefanou, S.; Acta Microbiol. Hell. 2008, 53, 83.

3. Tempesta, M. S.; Corley, D. G.; Beutler, J. A.; Metral, C. J.; Yunes, R. A.; Giacomozzi, C. A.; Calixto, J. B.; J. Nat. Prod. 1988, 51, 617.

4. Andricopulo, A. D.; Yunes, R. A.; Nunes, R. J.; Savi, A. O.; Corrêa, R.; Cruz, A. B.; Chechinel Filho, V.; Quim. Nova 1998, $21,573$.

5. Sortino, M.; Cechinel-Filho, V.; Corrêa, R.; Zacchino, S.; Bioorg. Med. Chem. 2008, 16, 560.

6. Khan, M.; J. Pharm. Sci. 1984, 73, 1767.

7. Mahle, F.; Guimarães, T. R.; Meira, A. V.; Corrêa, R.; Cruz, R. C. B.; Cruz, A. B.; Nunes, R. J.; Cechinel-Filho, V.; CamposBuzzi, F.; Eur. J. Med. Chem. 2001, 45, 4761.

8. Campos, B. F.; Correa, R.; Souza, M. M.; Yunes, R. A.; Nunes, R. J.; Cechinel-Filho, V.; Arzneimittelforschung 2002, 52, 455.

9. Rosolen, D.; Kretzer, I. F.; Winter, E.; Noldin, V. F.; Carmo, I. A. R.; Filippin-Monteiro, F. B.; Cechinel-Filho, V.; PasaCreczynski, T. B.; Chem.-Biol. Interact. 2016, 258, 10.

10. Costa, P. R. R.; Quim. Nova 2000, 23, 357.

11. Villegas, A. M.; Catalán, L. E.; Venegas, I. M.; García, J. V.; Altamirano, H. C.; Molecules 2011, 16, 4632.

12. Khayyat, S. A.; Al-Zahrani, S. H.; Arabian J. Chem. 2014, 7 , 800.

13. Khayyat, S. A.; J. Saudi Chem. Soc. 2013, 17, 61.

14. Lopes, R. O.; Romeiro, N. C.; Lima, C. K. F.; Silva, L. L.; Miranda, A. L. P.; Nascimento, P. G. B. D.; Cunha, F. Q.; Barreiro, E. J.; Lima, L. M.; Eur. J. Med. Chem. 2012, 54, 264.

15. Brando Lima, A. C.; Machado, A. L.; Simon, P.; Cavalcante, M. M.; Rezende, D. C.; Sperandio da Silva, G. M.; Nascimento, P. G.; Quintas, L. E.; Cunha, F. Q.; Barreiro, E. J.; Lima, L. M.; Koatz, V. L.; Pharmacol. Rep. 2011, 63, 1029.

16. Hudson, B. J. F.; Robinson, R.; J. Chem. Soc. 1941, 715.

17. Luis, J. A. S.; Costa, N. S.; Luis, C. C. S.; Lira, B. F.; AthaydeFilho, P. F.; Lima, T. K. S.; Rocha, J. C.; Scotti, L.; Scotti, M. T.; Curr. Med. 2020, 16, 39.
18. Silverstein, R. M.; Webster, F. X.; Kiemle, D. J.; Bryce, D. L.; Spectrometric Identification of Organic Compounds, $8^{\text {th }} \mathrm{ed}$.; John Wiley \& Sons: New York, 2015.

19. Bühl, M.; Van Mourik, T.; WIREs Comput Mol Sci. 2011, 1, 634.

20. Lodewyk, M. W.; Siebert, M. R.; Tantillo, D. J.; Chem. Rev. 2012, 112, 1839.

21. Smith, S. G.; Goodman, J. M.; J. Org. Chem. 2009, 74, 4597.

22. Smith, S. G.; Goodman, J. M.; J. Am. Chem. Soc. 2010, 132, 12946.

23. Ermanis, K.; Parkes, K. E. B.; Agback, T.; Goodman, J. M.; Org. Biomol. Chem. 2016, 14, 3943.

24. Ermanis, K.; Parkes, K. E. B.; Agback, T.; Goodman, J. M.; Org. Biomol. Chem. 2019, 17, 5886.

25. http://www.chemaxon.com/, accessed in June 2020.

26. Frisch, M. J.; Trucks, G. W.; Schlegel, H. B.; Scuseria, G. E.; Robb, M. A.; Cheeseman, J. R.; Scalmani, G.; Barone, V.; Mennucci, B.; Petersson, G. A.; Nakatsuji, H.; Caricato, M.; Li, X.; Hratchian, H. P.; Izmaylov, A. F.; Bloino, J.; Zheng, G.; Sonnenberg, J. L.; Hada, M.; Ehara, M.; Toyota, K.; Fukuda, R.; Hasegawa, J.; Ishida, M.; Nakajima, T.; Honda, Y.; Kitao, O.; Nakai, H.; Vreven, T.; Montgomery Jr., J. A.; Peralta, J. E.; Ogliaro, F.; Bearpark, M.; Heyd, J. J.; Brothers, E.; Kudin, K. N.; Staroverov, V. N.; Kobayashi, R.; Normand, J.; Raghavachari, K.; Rendell, A.; Burant, J. C.; Iyengar, S. S.; Tomasi, J.; Cossi, M.; Rega, N.; Millam, J. M.; Klene, M.; Knox, J. E.; Cross, J. B.; Bakken, V.; Adamo, C.; Jaramillo, J.; Gomperts, R.; Stratmann, R. E.; Yazyev, O.; Austin, A. J.; Cammi, R.; Pomelli, C.; Ochterski, J. W.; Martin, R. L.; Morokuma, K.; Zakrzewski, V. G.; Voth, G. A.; Salvador, P.; Dannenberg, J. J.; Dapprich, S.; Daniels, A. D.; Farkas, O.; Foresman, J. B.; Ortiz, J. V.; Cioslowski, J.; Fox, D. J.; Gaussian 09 Revision C.01; Gaussian, Inc.: Wallingford, CT, 2009.

27. Cheeseman, J. R.; Trucks, G. W.; Keith, T. A.; Frisch, M. J.; J. Chem. Phys. 1996, 104, 5497.

28. Lipinski, C. A.; Lombardo, F.; Dominy, B. W.; Feeney, P. J.; Adv. Drug Delivery Rev. 1997, 23, 3.

29. http://www.molinspiration.com/, accessed in June 2020.

30. http://www.swissadme.ch/, accessed in June 2020.

31. http://www.organic-chemistry.org/prog/peo/, accessed in June 2020.

32. Zhao, M. Y.; Abraham, M. H.; Le, J.; Hersey, A.; Luscombe, C. N.; Beck, G.; Sherborne, B.; Pharm. Res. 2002, 19, 1446.

33. Veber, D. F.; Johnson, S. R.; Cheng, H. U.; Smith, B. R.; Ward, K. W.; Kopple, K. D.; J. Med. Chem. 2002, 45, 2615.

34. Ali, J.; Camilleri, P.; Brown, M. B.; Hutt, A. J.; Kirton, S. B.; J. Chem. Inf. Model. 2012, 52, 2950.

35. Nascimento, P. F. C.; Nascimento, A. C.; Rodrigues, C. S.; Antoniolli, A. R.; Santos, M. P. O.; Júnior, A. M. B.; Trindade, R. C.; Rev. Bras. Farmacogn. 2007, 17, 108. 
36. Pereira, F. O.; Mendes, J. M.; Lima, I. O.; Mota, K. S. L.; Oliveira, W. A.; Lima, E. O.; Pharm. Biol. 2015, 53, 228.

37. National Committee for Clinical and Laboratory Standards (NCCLS); Performance Standards for Antimicrobial Disk Susceptibility Tests, $7^{\text {th }}$ ed.; NCCLS: Villanova, 2000.

38. Hadacek, F.; Greger, H.; Phytochem. Anal. 2000, 11, 137.
39. Cleeland, R.; Squires, E. In Evaluation of New Antimicrobials in vitro and in Experimental Animal Infections; Lorian, V., ed.; Antibiotics in Laboratory Medicine, Lippincott Williams \& Wilkins: Baltimore, 1991, p. 739.

Submitted: February 28, 2020

Published online: June 9, 2020 